\title{
A COMPARATIVE STUDY ON THE EFFECTS OF USING A ROLE PLAY AND A SMALL GROUP DISCUSSION TOWARDS THE SEVENTH GRADE STUDENTS' SPEAKING ACHIEVEMENT AT SMP NEGERI 1 BANJAR
}

\author{
N.K. Ningrum ${ }^{1}$, Sudirman ${ }^{2}$, N.K. Wedhanti ${ }^{3}$ \\ Jurusan Pendidikan Bahasa Inggris \\ Universitas Pendidikan Ganesha \\ Singaraja, Indonesia \\ e-mail: \{ningrumniketut@yahoo.com, dirman p@yahoo.co.id, karinawedhanti@yahoo.co.id\}@undiksha.ac.id
}

\begin{abstract}
ABSTRAK
Penelitian ini bertujuan untuk menyelidiki perbedaan dalam prestasi berbicara antara siswa yang diajar menggunakan permainan peran dan yang diajarkan menggunakan diskusi kelompok kecil. Penelitian menggunakan desain penelitian kuasi-eksperimental dengan post-test only control group design. Sampel penelitian adalah VII H dan VII G. VII H sebagai kelompok eksperimen yang terdiri dari 30 siswa dan VII G sebagai kelompok kontrol yang terdiri dari 32 siswa. Sampel diambil dengan teknik random sampling. Instrumen pengumpulan data adalah tes berbicara kinerja. Data dianalisis dengan menggunakan analisis deskriptif dan analisis inferensial. Hasil penelitian ini menunjukkan bahwa skor rata-rata kelompok eksperimen adalah 78.53, sedangkan skor rata-rata kelompok kontrol adalah 73.12. Kemudian, hasil pengujian hipotesis menunjukkan bahwa nilai sig. (2-tailed) adalah 0,001. Karena nilai sig $(0,001)<0,05$, jelas bahwa nilai tobs melebihi nilai $t_{c v}$. Dapat disimpulkan bahwa ada perbedaan dalam prestasi berbicara antara siswa yang diajar menggunakan permainan peran dan mereka yang diajarkan menggunakan diskusi kelompok kecil.
\end{abstract}

Kata kunci: Bermain peran, diskusi kelompok kecil, prestasi berbicara

\begin{abstract}
This study aimed at investigating if there was difference in speaking achievement between students who were taught using role play and those taught using small group discussion. This study used quasi-experimental research design with post-test only control group design. Samples of this study were VII $H$ and VII G. VII H as experimental group and VII G as control group. The samples were taken by random sampling technique. The instrument for collecting data was performance speaking test. The data were analyzed using descriptive analysis and inferential analysis. Result showed that mean score of experimental group was 78.53, while mean score of control group was 73.12. Hypothesis testing showed that the value of sig. (2-tailed) was 0.001 . Since the value of sig $(0.001)<0.05$, the value of $t_{\text {observed }}$

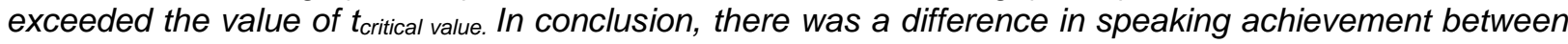
the two methods.
\end{abstract}

Keywords: Role play, small group discussion, speaking achievement 


\section{INTRODUCTION}

Speaking is one of the most important skills to be learned and enhanced as means of effective communication. Speaking is an interactive process of constructing meaning that involves producing, receiving, processing information and the presence of speaker and listener (Brown, 2001:267). It is one of the basic skills that should be taught to students. Besides, the students are expected be able to speak English fluently. They must have a good speaking skill that is used to communicate to other person for some interactions. Moreover, speaking skill is an essential in learning English as a foreign language (EFL) since learners make it necessary in sharing the information. In teaching English as a foreign language, speaking generally becomes a skill that is really significant to be learn in the classroom.

Generally, speaking is the most challenging skill that is learned by EFL learners especially by Junior High School students. They should learn the other sub-skills, namely pronunciation, vocabulary, grammar in order to speak English properly. According to Mappiase and Sihes (as cited in Kurniawati, 2016:3) argue that most of EFL learners are not brave to speak English because they are afraid in making a mistake. The students cannot be confident to speak English because they do not believe about their skill. They also do not have a chance to practice their speaking skills during the lesson in the classroom. It makes them have difficulties in expressing their opinion and their mind. Then, they are often reluctant because they have a low motivation in learning English. They are less practice to speak English in daily communication and they still use their first language as a tool for communication.

Another reason why such problem appears is due to the conventional technique used in the school. The teachers prefer to use the conventional teaching technique in the teaching and learning process. It makes the teachers are not very busy to prepare many things for teaching the students. Moreover, the teachers rarely give an opportunity to the students to practice directly and the students usually get an assignment or homework to accomplish the task. Those circumstances make the students are not motivated to learn English because of the teachers teach them monotonously. Furthermore, this phenomenon tends to make the students be passive during the speaking class. They do not want to express and participate in the classroom activities.

Nowadays, teaching speaking needs to enhance the students' communicative competence. It will make the students are able to express their feeling, their ideas and learn how to follow the social and the cultural rules which appropriate in each communicative circumstance (Susanti, 2007:07). Teaching speaking aims to teach the students about how produce English speech sounds and sounds pattern correctly. The students can select the appropriate words and sentences according to the proper social setting, audience, situation and the subject matter. Teaching speaking is really important because the students can express values and judgments quickly and confidently with a few unnatural pauses which is called fluency (Nunan, 2003:56).

The use of techniques can be emerged the students' interest and curiosity during the speaking class. The teaching technique is a procedure which is used to accomplish a specific activity or task in the classroom (Doliente, 2014:3). Through teaching technique, teachers are able to teach well and attract students' enthusiasm to learn English. This makes the teacher needs to implement an interesting teaching technique in teaching English. There are so many techniques that can be used to make the students easier to learn speaking as a foreign language. In this case, the researcher will apply role play and small group discussion in speaking class in order to create a good atmosphere in teaching speaking for the students.

Role play encourages thinking and creativity. It lets the students develop and practice new language and they can create their motivation in learning process. Ziafar, Toughiry \& Sadat (2014: 574) state that role play provides the students with opportunity to demonstrate how use English in the real situation. Role play is a created situation in which students deliberately act out or assume characters or identities they would not normally assume in order to accomplish learning goal (Barkley, 2005:150). Moreover, role play as a vehicle by which students can more easily learn the fundamentals of English conversation in a specific situation, requiring the use of key words which act as signifiers for that particular situation (Stocker, 2000:1). Nevertheless, 
teacher can design the activities in form of group, it makes the learners confidently follow the role in the classroom and show up their ability in speaking class.

Small group discussion is an interactive method which enables exchange of thoughts. According to Barker (as cited in Fowler, 1980: 310) states that small group discussion is three or more people interacting face to face, with or without an assigned leader in such a way that each person influences and is influenced by another person in the group. Moreover, according to Orlich (as cited in Antoni, 2014: 56) suggests that small group discussion could improve the students' speaking achievement. There are 3 reasons why we can use small group discussion in improving speaking skill. First discussion is used to increase teacher-student interaction and student-student verbal interaction in the classroom. Second, discussion is used to promote meaningful personal interaction and learning. The learning may be of contents, skills, attitudes or processes. Third, it is used to help students adopt more responsible and independent mode of learning. The benefits of small group discussion are to develop students' critical thinking, to share idea, opinion, and also experience to the others, and also build the positive attitude in participate a discussion. Furthermore, small group discussion can make the students more interested and more active in the learning process because it gives them an opportunity to share what topic that they get during the lesson.

Based on the situation and phenomenon which are explained above, both of role play and small group discussion can be implemented as the alternative for teaching speaking. By conducting this research, the researcher wants to know the effect of using role play and small group discussion toward the students' speaking achievement. Thus, this present study aims at answering this following question: Is there any significant difference in speaking achievement between the students who are taught by using role play and those are taught by using small group discussion?

\section{METHODS}

This research was conducted in Buleleng regency. The researcher used one specific school as the location of the study that was SMP Negeri 1 Banjar. The location of the school is in Banjar, Buleleng regency. Based on some considerations, this school was appropriate place for conducting the study. This school had a wide and various distribution population of the students from around Buleleng regency. Then, this school also had various students with different characteristics. So, this school could represent the students in general, especially in Buleleng regency.

This research was designed in a quasi-experimental research design. Quasi experimental was used in classroom experiments when the control group and the experimental group were such naturally assembled groups as intact classes, which might be similar. In this case, the researcher took two classes randomly as experimental group and control group which might have the same characteristics.

This research was conducted with post-test only control group design. This kind of design used two groups which were administered randomly, namely control group and experimental group. Each group had a different treatment where the control group used a small group discussion technique as the treatment whereas the experimental group used a role play technique as the treatment.

Subject is something which is being discussed, considered or studied for the purposes of research. The subject of this study is a number of students called population. From that, sample as the representative of this will be taken from the population mentioned.

According to Best (1981:8), population is any group of individuals that have one or more characteristics any group of individuals that have one or more characteristics in common. So, population of this research was the seventh-grade students of SMP Negeri 1 Banjar.

According to Best (1981:8), sample is a small proportion of a population selected for observation and analysis. In this research, the technique that is used of getting the sample is random sampling technique. Random sampling is a sampling technique to give an equal 
opportunity of all populations to be chosen as a sample (Agung, 2014:71). The sampling was applied by using lottery technique. From the lottery, VII $\mathrm{H}$ was as the experimental group that consisted of 30 students and VII G was as the control group that consisted of 32 students.

Before the treatment was conducted in both classes, normality and homogeneity testing was conducted. The tests were conducted in order to find out whether the two classes were normally distributed and homogeneous or not. The students' last speaking score was used to the test the normality and homogeneity between VII H and VII G.

Best $(1981: 238)$ states that research variables are the conditions that are manipulated, controlled, or observed by the researcher in research study. Here, there are two variables in this research; they are independent variable and dependent variable.

Independent variable is a stimulate variable which is measured, manipulated, or selected by the experimenter to determine its relationship to an observed phenomenon (Tuckman, 1978:58). In this research, the independent variable was role play and small group discussion towards speaking achievement for experimental group and control group. The experimental group used a role play while the control group used a small group discussion.

Dependent variable is response variable which is observed and measured to determine the effect of the independent variable (Tuckman, 1978:59). The dependent variable of this research was the students' speaking achievement. In this study, speaking achievement was defined as speaking score of the seventh-grade students of SMP Negeri 1 Banjar.

Research instruments are very important in order to collect the data. Research instrument is a device that is used to collect the data and to solve the research problem (Fraenkel \& Wallen, 1993: 101). In this research, the data was collected by the post-test. The post-test was used to look the students' progress in speaking after being given the treatment. There were several instruments that were used in this research, namely: speaking test, speaking scoring rubric and lesson plan.

According to Best \& Khan (as cited in Suryani, 2015:41) state that validity is the quality of the instrument or procedure that enables it to measure what is supposed to measure. Validity test was really important to check the instruments whether it was appropriate to be implemented or not. The content validity was checked by two expert judgments. There were four instruments that were validated by the experts, namely: 1) speaking posttest, 2) speaking scoring rubric, 3) lesson plan for control group, and 4) lesson plan for experimental group. In this study, the expert judgments used Gregory Formula to check the content validity of the instruments.

Moreover, Best \& Khan (as cited in Suryani, 2015:43) says that reliability is the degree of consistency that the instrument demonstrates, whether it is consistency or not. In this study, to check the reliability of the instruments, the instruments tried out at VII E of SMP Negeri 1 Banjar which was consisted of 32 students. Then, the students' speaking performance was evaluated by using speaking scoring rubric. There were two raters who gave the score for the students' speaking performance.

After collecting the data, the next step was to analyze the data that had been collected. The data were analyzed by using two forms of statistical analysis, they were: descriptive statistics and inferential statistics. According to Best \& Khan (as cited in Dewi, 2015:44) descriptive analysis involves the description of a particular group. The descriptive statistical analysis is analyzed data in terms of mean, median, mode, standard deviation, variance, maximum score and minimal score. Inferential statistics is used to analyze the significance of change between control and experimental group. The purpose of inferential analysis is to obtain the conclusion about the populations based on the observation of the sample (Candiasa, 2010:47).

\section{FINDINGS AND DISCUSSIONS}

This study was experimental study which focused on the significant difference of using role play and small group discussion on the students' speaking achievement. After six times of 
treatments, posttest was conducted to both of the groups. Then, the result of posttest was analyzed by descriptive analysis and inferential analysis.

After conducting the posttest in control and experimental groups, the result was analyzed descriptively. Descriptive statistic provides the information about mean, median, mode, standard deviation, variance, maximum score and minimum score. The data were analyzed by using SPPS 20.0. In this case processing summary was string up to conduct the descriptive statistics analysis. It was provided to convince the valid number. The descriptive statistical analysis is analyzed data in terms of mean, median, mode, standard deviation, variance, maximum score and minimal score.Mean is determined by summing the score in a distribution and divided it by the number of score in the distribution (Candiasa, 2010:25). The mean score of experimental group was 78.53 and the mean score of control group was 73.12. Mode is the frequent score in a distribution of score. It is the most score that is obtained by the students (Candiasa, 2010:27). The mode of experimental group was 84 which was attained by 7 students and the mode of control group was 76 which was attained by 9 students.

Median is the midpoint of the data (Candiasa, 2010:27). It is $50^{\text {th }}$ percentile, the point on the scale of measurement below which fifth percent of the score fall. The midpoint of experimental group was 80 and the midpoint of control group was 72 . Variance is a measurement of how the data distributes. This is the most important measure of dispersion, giving us information on the extent to which a set of scores varies in relation to the mean. The variance of experimental group was 45.77 and the variance of control group was 31.98. Standard deviation is the square root the variance (Candiasa, 2010:33). It is a measurement of the dispersion of a set data from its mean. The standard deviation of experimental group was 6.766 and the standard deviation of control group was 5.655. Maximum score is the highest score that appears on the data. The highest score of the experimental group was 92 and the highest score of control group was 84 . Minimum score is the lowest score that appears on the data. The lowest score of the experimental group was 64 and the lowest score of control group was 60.

Tests of Normality

After conducting the descriptive analysis for both experimental and control group, the result of the students' speaking score in posttest would be compared in order to see which one obtained the higher score and which one obtained the lower score. The mean score of experimental group was higher than the mean score of control group. The value of mode and median of experimental group was also higher than the value of mode and median of control group. The results above indicated that the students in experimental group had better performance rather than the students in control group in terms of speaking achievement.

Inferential analysis was conducted to find out whether the differences of the mean score of both experimental and control group were significant or not. The purpose of inferential analysis was to obtain the conclusion about the population based on the observation during the treatments of the sample. Before conducting the hypothesis testing (t-test), the data should have a normal distribution and the variance should be homogeneous. Therefore, the normality test and homogeneity test were conducted first.

The normality test was conducted before the hypothesis testing. This test was conducted in order to know whether the data obtained was normally distributed or not. When the value of data is less than (0.05), it means that the distribution of the data differs significantly from the normal distribution. In contrast, if the significance value of the data is more than 0.05 , it means that the data is categorized as normally distributed.

Table 1.1. The Result of Normality Test 


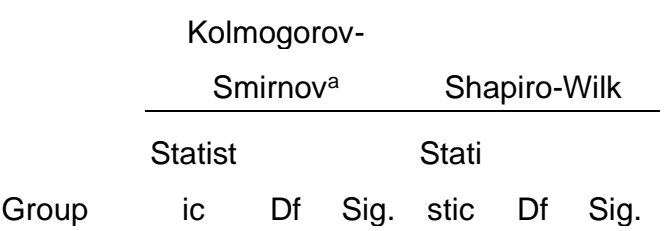

Score Experime

ntal $\quad .124 \quad 30^{.200} .968 \quad 30 \quad .490$

Group

Control

Group

Based on the table 1.1, it showed that the significant value based on Kolmogorov-Smirnov of experimental group was 0.200 and the control group was 0.058 . While, the significant value based on Shapiro-Wilk of experimental group was 0.490 and the control group was 0.076 . So, it indicated that both experimental group and control group were normally distributed.

The purpose of homogeneity test is to know whether the variance of the data are homogeneous or not. If the significance value of the data exceeds 0.05 , it can be said that the variances of the groups are equal. While if the significance value of the data is less than 0.05 , the data is not homogenous. Levene's statistic was used to test the homogeneity of the data.

Table 1.2. The Result of Homogeneity after Treatment

Test of Homogeneity of Variances

Levene

\begin{tabular}{crrr} 
Statistic & df1 & df2 & Sig. \\
\hline 1.928 & 1 & 60 & .170
\end{tabular}

The table 1.2 showed that the significant value of the data was 0.170 . It was exceeded 0.05. Thus, the data of the samples were homogeneous.

After the data were homogenous and normally distributed, parametric independent t-test was administrated. Independent sample t-test was used to measure the significant difference between the means of the two groups.

Table 1.3 Critical Value of t-distribution

\author{
Independent Samples Test
}

Levene's Test for

Equality of

Variances t-test for Equality of Means 


\begin{tabular}{|c|c|c|c|c|c|c|c|c|c|}
\hline & & & & & Sig. (2- & $\begin{array}{c}\text { Mean } \\
\text { Differen }\end{array}$ & $\begin{array}{c}\text { Std. } \\
\text { Error } \\
\text { Differenc }\end{array}$ & \multicolumn{2}{|c|}{$\begin{array}{c}\text { Interval of the } \\
\text { Difference }\end{array}$} \\
\hline & $\mathrm{F}$ & Sig. & $\mathrm{T}$ & Df & tailed) & $\mathrm{ce}$ & e & Lower & Upper \\
\hline Score Equal & & & & & & & & & \\
\hline $\begin{array}{l}\text { variances } \\
\text { assumed }\end{array}$ & 1.928 & .170 & 3.533 & 60 & .001 & 5.533 & 1.566 & 2.400 & 8.667 \\
\hline Equal & & & & & & & & & \\
\hline $\begin{array}{l}\text { variances not } \\
\text { assumed }\end{array}$ & & & 3.510 & 56.166 & .001 & 5.533 & 1.577 & 2.375 & 8.691 \\
\hline
\end{tabular}

The table 1.3 showed that the value of sig. (2-tailed) was 0.001 . Since the value of sig $(0.001)<0.05$, it was clear that $t_{o b s}$ exceeded $t_{c v}$. Thus, the $\mathrm{H}_{0}$ is rejected. It indicates that there is a significant difference in speaking achievement between the students who are taught by using role play and those are taught by using small group discussion.

After conducting the treatment, both experimental and control groups were given a posttest in the form of speaking performance test. Then, the score of students' posttest was analyzed by using descriptive analysis and inferential analysis in SPPS 20.0. Based on the descriptive analysis, the mean score of experimental group was 78.53, while the mean score of control group was 73.12. It indicated that the experimental group achieved higher score rather than the control group. Furthermore, the result of inferential analysis showed that that the value of sig. (2-tailed) was 0.001 . Since the value of sig $(0.001)<0.05$, it was clear that tobs exceeded $t_{c v}$. Thus, the $\mathrm{H}_{0}$ was rejected. It indicated that there was a significant difference in speaking achievement between the students who were taught by using role play and those were taught by using small group discussion.

Referring to the result of descriptive analysis and inferential analysis, it could be emphasized that the experimental group who were taught by using role play got a better achievement in speaking rather than the control group who were taught by using small group discussion. It indicated that role play technique was more effective in teaching speaking for the students.

The implementation of role play was running well. During the implementation of the roleplay technique, the students were happy and enjoyed the teaching and learning process because they could be performing in front of the class and acted freely. There were several steps in implementing role play technique in experimental group. The first step was the teacher gave knowledge to the students. The teacher explained the material and the students got the material. After giving the knowledge, the teacher explained about the use of role play technique for the next activity. The teacher gave a clear instruction what the student should do in the learning activity. Then, the teacher divided the students into several groups. After that, the teacher gave the situations and the students should acted out as a role play based on the situation given. The last activity in role play was discussing about the students' performance.

In the first meeting, the students were given the new material about describing people. The teacher explained the material, it was started by explaining about what is describing people, physical appearance and personality. The teacher explained it slowly until the students could understand the material. The teacher gave an example about how to describe people from the physical appearance first, then gave the example about how to describe people's personality. After giving the example, the teacher showed the picture to the students. The students were asked to describe the physical appearance based on the picture given. The teacher asked one by one students to describe the picture. From that activity, the teacher could 
teach speaking and the teacher gave the opportunities for the students to practice their speaking.

The second meeting, the teacher started the class by reviewing the previous meeting. The teacher gave several questions to the students to make sure that the students already understood about the material. After that, the teacher asked the students to work in pair and the teacher let the students to choose their partner freely. The class turned to be noisy as they were moving around the class to find their partner. After all the students got the partner, the teacher applied the role play technique in teaching speaking. The teacher gave a clear instruction about what the students should do in the group. Then, the students were given a situation. The students were asked to make a short conversation based on the situation given. In this activity, the teacher also gave the explanation about how to make the short conversation. After 15 minutes had left, the teacher asked every group to practice their short conversation in front of the class. After the performance, the teacher gave a comment and suggestion to their performance. This comment assisted them to improve their speaking achievement.

The implementation of role play technique at first time was still facing with a problem. There were some students who had still difficulties in creating a sentence based on the situation because most of them forgot to bring a dictionary. Moreover, the students was still confused about this activity because role play technique was a new for them. Relating with the problems, the teacher explained the activity in role play in detail and gave the example for the students. The students could understand the steps and they could play the role very well.

In third meeting, the teacher explained about the new material about describing animals. After explaining the material clearly, the teacher applied the role play technique again, but the teacher explained more detail about the role play before the role play was implemented. Some of the students already understood with the role play and they could follow the activity very well. In next meeting, the teacher explained the new material about describing things. The teacher explained the material by giving some handouts to the students. The students would be easier to understand about the materials. In the sixth meeting, the students were asked to play a role relating with describing things. The teacher gave some situations to the students and after that the students might present it in front of the class.

After implementing a role play technique for several times, the students already understood about the role play. They looked more enthusiast to follow the learning activity. The learning activity was not monotonous again and the students were enjoy with the learning activity. Then, the teacher conducted the posttest. The posttest was conducted in order to test the students' speaking achievement. In the posttest, the students' performance was scored by using the speaking scoring rubric. In the process of analyzing the students' speaking achievement, the students still had some problems. The problems were related about the students' pronunciation, content, accuracy, fluency and vocabulary. They could not express ideas, speak fluently, use right structures, lack of producing appropriate vocabulary and produce correct pronunciation.

However, after doing several treatments, it showed the previous problems that were faced by the students could be solved, especially their fluency and pronunciation became better. During the treatment, most of the students still did some mistakes in producing incorrect pronunciation and they were not fluent in speaking, but after they had practice every week during treatment sessions, a number of students showed a satisfactory progress in certain aspects in posttest.

In the control group, the result of the students' posttest was lower than the experimental group. The technique of the control group was a small group discussion. Small group discussion was applied to teach the students' speaking achievement in the control group. The students were interested in the learning activity because the students could develop their critical thinking through the small group discussion. By using this technique, the students could be more active, but some students were still passive and not all the students could give contribution during the discussion. Through the small group discussion, the students' speaking achievement was getting better and they didn't afraid again to speak English during the learning 
process. However, the outcome of the students' achievement was lower than the experimental group.

The use of the role-play technique in the teaching and learning process made some changes to the students and it gave some beneficial effect. The beneficial effect that could be given by using role play in teaching speaking are the students were motivated to join the teaching and learning process due to the role that was played by the students, the students seemed to enjoy the process of making dialogue and performing the role in front of the class.

\section{CONCLUSION AND SUGGESTION}

Based on the result of the t-test and the discussion, it can be concluded that there is a significant difference in speaking achievement between the students who are taught by using role play and those are taught by using small group discussion.

Students who were taught by using a role play technique obtained a better speaking score than those were taught by using small group discussion. The mean score of experimental group was 78.53, while the mean score of control group was 73.12. Moreover, the result of ttest showed that the value of sig. (2-tailed) was 0.001 . Since the value of sig $(0.001)<0.05$, it was clear that $t_{\text {obs }}$ exceeded $t_{c v}$. Thus, the $\mathrm{H}_{0}$ is rejected. It can be concluded that there is a significant difference in speaking achievement between the students who are taught by using role play and those are taught by using small group discussion.

By comparing the different average scores on both groups, the writer is able to conclude that a role play as technique gave more contribution than a small group discussion to improve the students' speaking achievement. So, it means that the role play technique is more effective to be used in teaching speaking.

Based on the discussion, the researcher would like to propose some suggestions, they are:

a. For English Teacher

It is suggested that a role play can be applied when the English teacher faces some difficulties in teaching speaking, especially for junior high school. This technique could make the students more active, more enthusiast and more creative during the speaking class.

b. For Other Researchers

It is better for the other researcher that would conduct the same study to use this study as a guidance to get deeper result. This study could be used to inspire the other researchers and give more idea about teaching speaking in junior high school.

\section{REFERENCES}

Antoni, Rivi. (2014). Teaching Speaking Skill through Small Group Discussion Technique at the Accounting Study Program. Journal of Education and Islamic Studies Vol. 5, Num. 1, January-June 2014.

Barkley, Elizabeth F., K. Patricia Cross, and Claire Howell Major. (2005). Collaborative Learning Techniques. A handbook for College Faculty. San Francisco: Jossey-Bass Publisher

Best, J.W. (1981). Research in Education. 4th Ed. New Jersey: Prentice Press.

Brown, D. H. (2001). Principles of Language Learning and Teaching. Englewood Cliffs. New Jersey: Prentice Press

Candiasa, I Made. 2010a. Statistik Univariat dan Bivariat Disertai Aplikasi SPSS. Singaraja: Undiksha Press. 
Doliente, Justin. (2014). Principles of Teaching: Different Methods and Approaches. The OnLine Journal of Research (On-line serial). Retrieved February 25, 2018 from https://www.slideshare.net/justindoliente/princliples-of-teaching-33070911

Fowler, William. (1980). Infant and Child Care: A Guide to Education Gorup Settings. New York: Allyn and Bacon Inc.

Fraenkel, J.R \& Wallen, N. E. (1993). How to Design and Evaluate Research in Education. New York: Mcgraw-Hill.

Kurniawati, L.K. (2016). The effect of round robin tecnique on the speaking achievement of the $7^{\text {th }}$ of SMP Negeri 4 Singaraja in the academic year of 2015/2016. Singaraja: Ganesha University of Education.

Nunan, D. (2003). Practical English Language Teaching (1st ed). New York: McGraw-Hill

Stocker, D. (2000). English Language Teaching Articles: ESL Role-play. Retrieved May 20, 2017, from http://www.eslbase.com/articles/roleplay.asp

Suryani, L. (2015). The Effectiveness of Role Play in Teaching Speaking. ELTIN journal.

Susanti, A.D.H. (2007). Using Role-Play in Teaching Speaking Skill. Jakarta: Unpublished dissertation.

Tuckman, B.W. (1978). Conducting Educational Research. London: Harcourt Jacobvitz.

Ziafar, M., Toughiry, N., \& Sadat, H.Z. (2014). The Relationship between Teaching Conversational through Role Play anf the Students' Speaking Develepment. International Journal of Languange Learning an Applied Linguistics World Journal.5(1). 547-553. Retrieved on February 25, 2018 from http:/www.ijllalw.org/finalversion5142.pdf 